\title{
PHOSPHORUS SOURCES AND FRACTIONS IN AN OXISOL UNDER NO-TILLED SOYBEAN
}

\author{
Raquel Galvani ${ }^{1}$; Luiz Fernando Keyti Hotta ${ }^{1}$; Ciro Antonio Rosolem²* \\ ${ }^{1}$ UNESP/FCA - Programa de Pós-Graduação em Agronomia. \\ ${ }^{2}$ UNESP/FCA - Depto. de Produção Vegetal, C.P. 237 - 18603-970 - Botucatu, SP - Brasil. \\ *Corresponding author <rosolem@fca.unesp.br>
}

\begin{abstract}
Phosphorus dynamics in soil can be modified by the use of no-till systems. Brazilian farmers have applied phosphorus fertilizers onto the soil surface to optimize machine field operations despite the lack of research supporting this practice. An experiment was conducted to study the effects of the application of two P sources onto soil surface and soybean seed furrows. The treatments consisted either of the application or not of $80 \mathrm{~kg} \mathrm{ha}^{-1}$ of total $\mathrm{P}_{2} \mathrm{O}_{5}$ as natural reactive rock phosphate and superphosphate spread on the soil surface over the standing plant residues. At soybean planting, additional treatments ( $80 \mathrm{~kg} \mathrm{ha}^{-1}$ of Natural Phosphate or Superphosphate) were applied at seed furrows. Soil was sampled down to $40 \mathrm{~cm}$ deep before soybean planting and after harvest. A control sample was taken from an adjacent non-cropped area. Phosphorus contents increased down to $40 \mathrm{~cm}$ after the soybean crop, and the increase was observed mainly in Ca-bound P and organic phosphorus. However, there was a decrease in Fe-bound P, showing that P availability to soybeans was likely related also to this fraction. Phosphorus fertilization with both phosphates decreased occluded $\mathrm{P}$ contents on the soil surface layer when compared with the non-cropped area.

Key words: natural phosphate, phosphorus fertilizer, mineral phosphorus, organic phosphorus, phosphorus fractioning
\end{abstract}

\section{FONTES E FRAÇÕES DE FÓSFORO NUM LATOSSOLO SOB SEMEADURADIRETADE SOJA}

\begin{abstract}
RESUMO: A dinâmica do P no solo pode ser modificada em sistemas com semeadura direta. Os agricultores brasileiros vêm aplicando fósforo na superfície do solo para otimizar a operação de máquinas, embora não seja uma prática recomendada pela pesquisa. Foi conduzido um experimento para estudar os efeitos da aplicação de duas fontes de fósforo na superfície do solo e no sulco de semeadura da soja. Os tratamentos consistiram da aplicação ou não de $80 \mathrm{~kg} \mathrm{ha}^{-1}$ de $\mathrm{P}$ total como fosfato natural reativo e superfosfato, aplicados na superfície do solo, sobre os resíduos da cultura anterior. Na semeadura da soja, tratamentos adicionais ( $80 \mathrm{~kg} \mathrm{ha}^{-1}$ de fosfato natural ou superfosfato) foram aplicados ao sulco de semeadura. O solo foi amostrado até $40 \mathrm{~cm}$ de profundidade, antes da semeadura da soja e após a colheita. Uma amostra controle foi tomada de área adjacente, sem cultivo. Houve aumento nos teores de $\mathrm{P}$ até $40 \mathrm{~cm}$ de profundidade, após a colheita da soja, de modo que o aumento foi observado principalmente no P ligado ao Ca e no P orgânico. Entretanto houve decréscimo nos teores de $\mathrm{P}$ ligado ao Fe. A adubação com ambas as fontes de fosfato levaram a um decréscimo nos teores de P ocluso na superfície do solo quando comparada com a área sem cultivo.

Palavras-chave: fosfato natural, fertilizante fosfatado, fósforo mineral, fósforo orgânico, fracionamento de fósforo
\end{abstract}

\section{INTRODUCTION}

Inorganic $\mathrm{P}$ occurs in soil mainly as $\mathrm{H}_{2} \mathrm{PO}_{4}$ - and $\mathrm{HPO}_{4}^{2-}$, adsorbed to $\mathrm{Fe}$ and $\mathrm{Al}$ oxides and hydroxides and to organic matter or bound to Ca (Raij, 1991). The relative proportions of inorganic and organic $\mathrm{P}$ range widely among soils, but it is usual that organic P accounts for more than a half of total P (Almeida et al., 2003). Soil $P$ forms, contents and distribution are affected by soil parent material and management
(Machado et al., 1993). In no-till systems, the maintenance of plant residues and phosphate application over the soil surface lead to the formation of P concentration gradients, characterized by a large vertical variability in the concentrations of this nutrient within the profile (Eltz et al., 1989; Selles et al., 1997; Schlindwein \& Anghinoni, 2000).

During the implantation of no-till systems, when tilling is interrupted, contact of phosphate ions with sorption sites is decreased, which can affect phos- 
phate dynamics in soil (Vernetti Júnior \& Gomes, 1999). The knowledge of the behavior of phosphorus in no-till systems and its relation with the organic matter has allowed the use of alternative less soluble $\mathrm{P}$ sources such as natural reactive rock phosphates as substitutes for soluble sources (Vernetti Júnior \& Gomes, 1999). Reactive rock phosphates fragments are very porous and this porosity increases the specific contact area and accelerates their effect. However, the knowledge about the effects of phosphates when applied on the soil surface is limited, mainly in tropical environments. A relevant point is the increase in organic phosphorus in relation to total phosphorus in several soils maintained for a long time under notill (Bartz, 1998). These results point to the redistribution of organic fractions of $\mathrm{P}$ within the soil profile at depths where the availability of inorganic phosphorus fractions is very low. This may happen as a consequence of the decomposition of plant residues and root systems. Non-labile fractions of $\mathrm{P}$ tend to decrease in relation to total $\mathrm{P}$ with cropping time along with a relative increase in more labile fractions, that is, more available P forms (Tokura et al., 2002).

An improved knowledge of $\mathrm{P}$ distribution and pools in the soil profile is important in understanding the behavior of this nutrient in the soil plant system, mainly under no-till in tropical regions. This knowledge will allow planning a more appropriate management of phosphate fertilization in the production system. This work was designed to study the distribution of phosphorus fractions at four depths, until $40 \mathrm{~cm}$, in the soil profile under a no-till crop rotation with soybean as affected by the application of two sources of phosphorus.

\section{MATERIAL AND METHODS}

The experiment was conducted in a sandy loamy Haplortox, in Botucatu, State of São Paulo, Brazil (altitude of 786 m, 22 $2^{\circ} 49^{\prime}$ S, 48 $25^{\circ}$ W). Soybean (Glycine max (L) Merril) was grown in the experimental site during two seasons (1999/2000 and 2000/2001) under no-till, in rotation with black oats (Avena strigosa) in the winter and pearl millet (Pennisetum glaucum) in the spring. Selected chemical (Raij et al., 2001) and granulometric (Embrapa, 1997) properties of the soil are in Table 1.

In April 2001, triticale (X Triticosecale Wittmack) was planted over the standing straw and three treatments were applied to field plots, considering the total $\mathrm{P}_{2} \mathrm{O}_{5}$ content of the fertilizer: $80 \mathrm{~kg} \mathrm{ha}^{-1}$ $\mathrm{P}_{2} \mathrm{O}_{5}$ as powder triple superphosphate (soluble phosphate), $80 \mathrm{~kg} \mathrm{ha}^{-1} \mathrm{P}_{2} \mathrm{O}_{5}$ as ground Arad phosphate (reactive), and control (without phosphate fertilizer). The plots were $30 \mathrm{~m}$ long and $8 \mathrm{~m}$ wide, with four replicates. The fertilizers were spread on the soil surface over the previous crop residues. All plots received 50 $\mathrm{kg} \mathrm{ha}^{-1} \mathrm{~K}_{2} \mathrm{O}$ as $\mathrm{KCl}$ and $100 \mathrm{~kg} \mathrm{ha}^{-1}$ of Phosphogypsum, also spread on the soil surface. In September 2001, millet was planted in the experimental area after triticale harvesting. In November 2001, after chemical desiccation of millet, the soil was sampled at layers 0 5, 5 - 10, 10 - 20, and $20-40 \mathrm{~cm}$ deep. Six subsamples were taken randomly per plot to compose one sample that was analyzed.

After this, soybean was planted in sub-plots 5.0 $\mathrm{m}$ long and $8.0 \mathrm{~m}$ wide. The following treatments were applied: 1) $80 \mathrm{~kg} \mathrm{ha}^{-1} \mathrm{P}_{2} \mathrm{O}_{5}$ (simple superphosphate) in the plots that were previously treated with soluble phosphate (triple superphosphate); 2) $80 \mathrm{~kg} \mathrm{ha}^{-1} \mathrm{P}_{2} \mathrm{O}_{5}$ (simple superphosphate) in the plots treated with natural rock phosphate (reactive); 3) $80 \mathrm{~kg} \mathrm{ha}^{-1} \mathrm{P}_{2} \mathrm{O}_{5}$ (reactive) in the plots treated with reactive phosphate (Arad); 4) $80 \mathrm{~kg} \mathrm{ha}^{-1} \mathrm{P}_{2} \mathrm{O}_{5}$ (reactive) in the plots treated with soluble phosphate (triple superphosphate); 5) 80 $\mathrm{kg} \mathrm{ha}^{-1} \mathrm{P}_{2} \mathrm{O}_{5}$ (simple superphosphate) in the control plots; 6) $80 \mathrm{~kg} \mathrm{ha}^{-1} \mathrm{P}_{2} \mathrm{O}_{5}$ (reactive) in the control plots; and 7) absolute control (soil sampled in a non-cropped, identical area adjacent to the experiment). For the control, six sub-samples were taken to compose one sample, and replicates were taken North, South, East and West of the treated plots. Soybean was fertilized with $60 \mathrm{~kg} \mathrm{ha}^{-1} \mathrm{~K}_{2} \mathrm{O}$ as $\mathrm{KCl}$, applied along with the phosphates approximately $5.0 \mathrm{~cm}$ below and $5.0 \mathrm{~cm}$ aside the seeds. After soybean harvest in April 2002, the soil was sampled again at layers $0-5,5-10,10$ - 20, and 20 - $40 \mathrm{~cm}$ deep.

Table 1 - Selected soil chemical characteristics ${ }^{(1)}$ and soil particle distribution ${ }^{(2)}$ by the time the experiment was started.

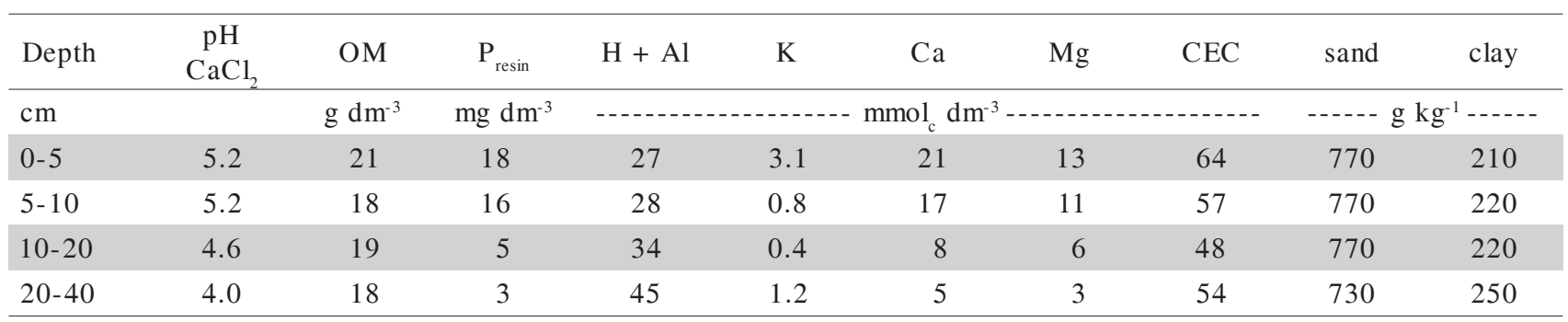

${ }^{1}$ Raij et al., (2001), ${ }^{2}$ EMBRAPA (1997). 
Phosphorus fractions in soil were determined as in Catani \& Bataglia (1968). It was sequentialy extrated and determined: 1) water soluble P; 2) phosphorus fractions weakly bound to soil (extraction with $\mathrm{NH}_{4} \mathrm{Cl} 1 \mathrm{~mol} \mathrm{~L}^{-1}$ ); 3) phosphorus bound to aluminum (Al-bound $\mathrm{P}$, extraction with $\mathrm{NH}_{4} \mathrm{~F} 5.5 \mathrm{~mol} \mathrm{~L}^{-1}$ at $\mathrm{pH}$ 8.5); 4) phosphorus bound to iron (Fe-bound P, extraction with $\mathrm{NaOH} 0.1 \mathrm{~mol} \mathrm{~L}^{-1}$ ); 5) phosphorus bound to calcium (Ca-bound $\mathrm{P}$, extraction with $\mathrm{H}_{2} \mathrm{SO}_{4} 0.5 \mathrm{~mol}$ $\mathrm{L}^{-1}$ ); 6) occluded phosphorus (by attack with $\mathrm{HCl}$, $\mathrm{HNO}_{3}$, and $\mathrm{H}_{2} \mathrm{SO}_{4}$, after the previous extractions); 7) organic phosphorus was determined by difference between the content extracted from a soil sample submitted to $550^{\circ} \mathrm{C}$ with a solution of $\mathrm{H}_{2} \mathrm{SO}_{4} 0.5 \mathrm{~mol} \mathrm{~L}^{-1}$ and the content extracted with the same solution without heating.

The experimental design was a sup-plot (three plots and six sub-plots), with an additional treatment (absolute control), with four replicates. ANOVA was carried out and means were compared using the t-test (LSD, $p<0.05$ ).

\section{RESULTS AND DISCUSSION}

\section{Effect of cropping on soil $P$ fractions}

Water soluble phosphorus contents in the plots treated with phosphate fertilizer were higher than that found in the control area down to $10 \mathrm{~cm}$ deep (Table $2)$. In the control area, the contents were null. These results were expected as a result of the phosphate fertilization and the dynamics of the plant residues accumulated on the soil, which can release the nutrient as it decomposes. Lower inorganic P contents down to $10 \mathrm{~cm}$ in non-cropped areas had been observed before (Tokura et al., 2002). The differences were attributed to time, farming system, and soil type. In the present

Table 2 - Phosphorus contents in the soil profile in four depths, at samplings before soybean planting and after soybean harvest, in the control area and in treated plots. Average of four replicates.

\begin{tabular}{|c|c|c|c|c|}
\hline \multirow{2}{*}{ Treatments } & \multicolumn{4}{|c|}{ Depths $(\mathrm{cm})$} \\
\hline & $0-5$ & $5-10$ & $10-20$ & $20-40$ \\
\hline & $-\cdots$ & $-\cdots$ & 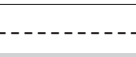 & $-\cdots$ \\
\hline \multicolumn{5}{|c|}{ P - water } \\
\hline Control area & 0 & 0 & 0 & 0 \\
\hline Treatment average $1^{1}$ & $13 *$ & $1 *$ & 0 & 0 \\
\hline Treatment average $2^{2}$ & $4 *$ & $2 *$ & $2 *$ & $1 *$ \\
\hline \multicolumn{5}{|c|}{$\mathrm{P}-\mathrm{Al}$} \\
\hline Control area & 2 & 4 & 4 & 2 \\
\hline Treatment average $1^{1}$ & $0 *$ & $0 *$ & $0 *$ & $1 *$ \\
\hline Treatment average $2^{2}$ & $3 *$ & $3 *$ & $3 *$ & $3 *$ \\
\hline \multicolumn{5}{|c|}{$\mathrm{P}-\mathrm{Fe}$} \\
\hline Control area & 197 & 180 & 197 & 186 \\
\hline Treatment average $1^{1}$ & $253 *$ & $197 *$ & $191 *$ & $161 *$ \\
\hline Treatment average $2^{2}$ & $167 *$ & $134 *$ & $138 *$ & $107 *$ \\
\hline \multicolumn{5}{|c|}{$\mathrm{P}-\mathrm{Ca}$} \\
\hline Control area & 99 & 76 & 76 & 72 \\
\hline Treatment average $1^{1}$ & $180 *$ & $108 *$ & $113 *$ & $107 *$ \\
\hline Treatment average $2^{2}$ & $170 *$ & $118^{*}$ & $126 *$ & $95 *$ \\
\hline \multicolumn{5}{|c|}{ P occluded } \\
\hline Control area & 694 & 537 & 635 & 667 \\
\hline Treatment average $1^{1}$ & $633 *$ & $609 *$ & $647 *$ & $712 *$ \\
\hline Treatment average $2^{2}$ & $673 *$ & $618 *$ & $602 *$ & $790 *$ \\
\hline \multicolumn{5}{|c|}{$\mathrm{P}$ organic } \\
\hline Control area & 92 & 102 & 98 & 84 \\
\hline Treatment average $1^{1}$ & $107 *$ & $79 *$ & $68 *$ & $80 *$ \\
\hline Treatment average $2^{2}$ & $131 *$ & $120 *$ & $120 *$ & $99 *$ \\
\hline
\end{tabular}

*Significant difference (LSD, $p<0.05$ ) as compared with the result in the control area. ${ }^{1}$ Treatments average before soybean planting.

${ }^{2}$ Treatments average after soybean harvest. 
experiment, after soybean harvesting, water soluble $\mathrm{P}$ was found down to $40 \mathrm{~cm}$ deep in the soil profile, showing that soybean cropping and time had an effect on the soil P pools (Table 3).

There was no detectable Al-bound $\mathrm{P}$ in the treated area before soybean planting, except for the layer at $20-40 \mathrm{~cm}$ (Table 2). However, in this case, the contents in the control area, down to $40 \mathrm{~cm}$ deep, were larger than those in the treated area. In this kind of soil, Al-bound $\mathrm{P}$ is found in lower concentrations as compared with other phosphorus fractions, which reflects the high weathering stage of the soils (Barbosa Filho et al., 1987). With the increase in acidity by the removal of exchangeable basis, there is an increase in $\mathrm{Fe}$ and $\mathrm{Al}$ activity and the more soluble fractions of $\mathrm{P}$ bound to $\mathrm{Ca}$ are converted to phosphorus bound to $\mathrm{Al}$ and Fe (Chang \& Jackson, 1958). The soil in the current experiment has low $\mathrm{Al}$ content, thus Fe predomi- nates. Therefore, it is possible that liming (done two years before this experiment was started), by increasing soil base saturation and $\mathrm{pH}$ (Table 1), along with the transport of organic acids from decomposing plant material, led to soil Al complexation (Rosolem et al., 2004) and the absence of Al-bound P in the treated plots before soybean was planted. However, after soybean harvest, Al-bound $\mathrm{P}$ was found again in the soil profile. The fixation of $\mathrm{N}_{2}$ may result in soil acidification, resulting in more $\mathrm{Al}$ in solution, which may explain the appearance of Al-bound P after soybean harvest.

The contents of Fe-bound $\mathrm{P}$ before soybean planting were greater in the treated plots in relation to those of the control area in layers 0 - 5 and 5 - $10 \mathrm{~cm}$ deep and lower in layers 10 - 20 and 20 - $40 \mathrm{~cm}$ (Table 2). This may result from the action of fertilizers and the organic acids leached from the straw left on the soil surface that may complex some Fe. In contrast,

Table 3 - Soil phosphorus in the soil profile before soybean planting as affected by phosphates applied to triticale.

\begin{tabular}{|c|c|c|c|c|}
\hline \multirow{2}{*}{ Treatments } & \multicolumn{4}{|c|}{ Depths $(\mathrm{cm})$} \\
\hline & $0-5$ & $5-10$ & $10-20$ & $20-40$ \\
\hline \multicolumn{5}{|c|}{ mg $\mathrm{dm}^{-3}$} \\
\hline \multicolumn{5}{|c|}{ water soluble $\mathrm{P}$} \\
\hline $\mathrm{NP}^{1}$ & 9 & 2 & 0 & 0 \\
\hline $\mathrm{RP}^{2}$ & 12 & $0 *$ & 0 & 0 \\
\hline $\mathrm{SP}^{3}$ & $18 *$ & 1 & 0 & 0 \\
\hline \multicolumn{5}{|c|}{ Al-bound P } \\
\hline $\mathrm{NP}^{1}$ & 1 & 0 & 0 & 0 \\
\hline $\mathrm{RP}^{2}$ & 0 & 1 & 1 & 0 \\
\hline $\mathrm{SP}^{3}$ & 0 & 0 & 1 & $3 *$ \\
\hline \multicolumn{5}{|c|}{ Fe-bound $\mathrm{P}$} \\
\hline $\mathrm{NP}^{1}$ & 238 & 191 & 175 & 160 \\
\hline $\mathrm{RP}^{2}$ & 306 & 249 & 218 & 172 \\
\hline $\mathrm{SP}^{3}$ & $214 * *$ & $150 * *$ & 179 & 151 \\
\hline \multicolumn{5}{|c|}{ Ca-bound $\mathrm{P}$} \\
\hline $\mathrm{NP}^{1}$ & 111 & 117 & 91 & 80 \\
\hline $\mathrm{RP}^{2}$ & $289 *$ & 108 & 115 & 132 \\
\hline $\mathrm{SP}^{3}$ & $139 * *$ & 98 & $133 *$ & 110 \\
\hline \multicolumn{5}{|c|}{ occluded P } \\
\hline $\mathrm{NP}^{1}$ & 633 & 643 & 591 & 757 \\
\hline $\mathrm{RP}^{2}$ & 668 & 658 & $759 *$ & 692 \\
\hline $\mathrm{SP}^{3}$ & 598 & 557 & $591 * *$ & 688 \\
\hline \multicolumn{5}{|c|}{ organic $\mathrm{P}$} \\
\hline $\mathrm{NP}^{1}$ & 102 & 77 & 69 & 86 \\
\hline $\mathrm{RP}^{2}$ & 108 & 83 & 66 & 64 \\
\hline $\mathrm{SP}^{3}$ & 112 & 77 & 70 & 88 \\
\hline
\end{tabular}


at soybean harvest, Fe-bound P content was higher in the control area than in the treated plots, showing the importance of farming in the dynamics of the fractions of $\mathrm{P}$ in soil, because available $\mathrm{P}$ was related, at least in part, to this fraction. It had been observed before that this fraction of $\mathrm{P}$ in tropical soil is more dynamic than that usually reported in the international literature and therefore, at least part of it may have been absorbed by the plants (Rheinheimer \& Anghinoni, 2000).

The treated area presented a larger content of Ca-bound $\mathrm{P}$ than that found in the control area (Table 2). The application of $\mathrm{P}$ fertilizers and $\mathrm{Ca}$ amendments may account for the increase in this $\mathrm{P}$ fraction.

The content of occluded phosphorus in the plots that received phosphate before soybean planting was smaller than those observed the top layers (0 - 5 and $5-10 \mathrm{~cm}$ ) and higher than those found in the deepest layer in the control area (Table 2). After soybean harvest, greater contents of occluded phosphorus were observed in the $20-40 \mathrm{~cm}$ layer in plots treated with phosphate, while the largest contents of occluded phosphorus were found in the control area, in layers 0 - 5 and $10-20 \mathrm{~cm}$ deep. Soil modifications by cropping, along with successive and prolonged use of phosphate fertilizers, may increase the content of $\mathrm{P}$ and alter its fractions in soil. During the time between the two samplings, there was a slight increase in occluded soil phosphorus in the treated plots.

As to organic P, before soybean planting, the treated plots showed larger contents than the noncropped top soil layer (Table 2), in contrast with the results found down in the soil profile. It is common an increase in the percentage of organic phosphorus in relation to total phosphorus in zero tillage systems (Bartz, 1998). The decomposition of plant material on the surface and in the soil releases organic acids continually, which makes nutrients available for the crops (Bayer \& Mielniczuk, 1999). In the present experiment, in general, after soybean harvest, there was an increase in organic P contents in soil as compared with those observed before soybean planting and in the control area. Several papers have shown the effect of different organic acids on phosphorus availability (Sidiras \& Pavan, 1985), allowing the inferrence that organic acids released by rizosphere and by decomposition of plant residues can affect $\mathrm{P}$ dynamics, decreasing adsorption and precipitaiton rates and, thus, increasin bioavalability of inorganic $P$.

\section{Effects of phosphorus sources}

Before soybean planting, the contents of water soluble $\mathrm{P}$ in soil were very low or null, with the exception of the $0-5 \mathrm{~cm}$ layer, where the soluble phosphate application, as expected, led to higher val- ues (Table 3). The phosphate ions released by the dissolution of soluble fertilizers added to the soil can be adsorbed or precipitated (Raij, 1991). In contrast, according to Smith (1968), the addition of less soluble phosphate fertilizers to soil may result in lower P sorption, which was not observed in the present work.

Al bound $\mathrm{P}$ was not affected by the use of fertilizers (Table 3), being the concentrations rather low or null. In the case of Fe-bound P, the plots that received natural reactive phosphate (NP) presented a higher content in the $0-5$ and $5-10 \mathrm{~cm}$ layers as compared with those $0-5$-and $5-10-\mathrm{cm}$ treated with soluble phosphate (SP) (Table 3). In the $0-5 \mathrm{~cm}$ layer, the use of NP at the time of triticale planting resulted in a larger content of Ca-bound P comparatively to the results of other treatments. In the $10-20 \mathrm{~cm}$ layer SP led to a larger Ca-bound P content in relation to the absence of phosphate fertilizer. The use of phosphorus sources containing calcium on soil surface at the time of triticale planting and the larger content of calcium in NP may have contributed to this result.

The use of NP generally resulted in greater contents of occluded P, although differences were observed only in the $10-20 \mathrm{~cm}$ layer (Table 3). There were no differences in organic $\mathrm{P}$ contents between the treatments within a particular layer (Table 3). Nevertheless, the absolute values show a gradient with higher organic P contents on the soil surface. In fact, organic P tends to be less adsorbed (Sidiras \& Pavan, 1985) and movement in soil profile could be greater when compared with inorganic $\mathrm{P}$ forms. Also, organic $\mathrm{P}$ does not precipitate as inorganic P. On the other side, competition by sorption sites between organic compounds released by plant roots or plant residues and inorganic and organic P can increase also vertical movement (Jones, 1998).

After soybean harvest, although the contents of P weakly bound to soil remained very low, it was found some $\mathrm{P}$ in this form in practically all the situations studied (Table 4). However, a greater content of this $\mathrm{P}$ fraction was found with the application of SP on plots that received NP. This would be expected, considering the application of soluble phosphate. The problem is that, in this case, it could have also been expected that the use of soluble phosphate on plots that had been fertilized with soluble phosphate would lead to a similar result, which did not happen. Additionally, in the case of Al-bound P, despite its low contents, there was $\mathrm{P}$ in this form in all the situations studied (Table 4), but it was not observed any effect of the treatments.

At harvest, application of soluble phosphate to soybean led to higher contents of Fe-bound P down to $40 \mathrm{~cm}$ deep, than those obtained in plots without 
Table 4 - Mean phosphorus contents in the soil profile at soybean harvest, as affected by P sources and way of applications.

\begin{tabular}{|c|c|c|c|c|c|c|c|c|}
\hline \multirow{3}{*}{$\begin{array}{l}\text { P source } \\
\text { applied to } \\
\text { triticale }\end{array}$} & \multicolumn{8}{|c|}{ Depths $(\mathrm{cm})$} \\
\hline & \multicolumn{2}{|c|}{$0-5$} & \multicolumn{2}{|c|}{$5-10$} & \multicolumn{2}{|c|}{$10-20$} & \multicolumn{2}{|c|}{$20-40$} \\
\hline & $\mathrm{RP}^{1}$ & $\mathrm{SP}^{2}$ & $\mathrm{RP}$ & $\mathrm{SP}$ & $\mathrm{RP}$ & SP & RP & SP \\
\hline & \multicolumn{8}{|c|}{ - } \\
\hline & \multicolumn{6}{|c|}{ water soluble $\mathrm{P}$} & & \\
\hline NP3 & 1 & 3 & 1 & 1 & 5 & 1 & 0 & 0 \\
\hline RP4 & 4 & $1+*$ & 2 & 5 & 1 & 2 & 1 & 1 \\
\hline \multirow[t]{2}{*}{ SP5 } & 2 & 3 & 1 & 2 & 1 & 0 & 1 & 1 \\
\hline & \multicolumn{8}{|c|}{ Al-bound $\mathrm{P}$} \\
\hline $\mathrm{NP}$ & 3 & 3 & 3 & 3 & 3 & 2 & 4 & 3 \\
\hline $\mathrm{RP}$ & 3 & 3 & 3 & 3 & 2 & 3 & 3 & 3 \\
\hline \multirow[t]{2}{*}{ SP } & 3 & 3 & 3 & 3 & 3 & 3 & 4 & 3 \\
\hline & \multicolumn{8}{|c|}{ Fe-bound $\mathrm{P}$} \\
\hline $\mathrm{NP}$ & 102 & 101 & 61 & 179 & 75 & $194+$ & 56 & $142+$ \\
\hline $\mathrm{RP}$ & $4 *$ & $244+$ & $2 *$ & 199 & 1 & $177+$ & 1 & $138+$ \\
\hline \multirow[t]{2}{*}{$\mathrm{SP}$} & $213 *$ & 258 & $186 *$ & 177 & $206 *$ & 171 & $171 *$ & 136 \\
\hline & \multicolumn{8}{|c|}{$\mathrm{P}-\mathrm{Ca}$} \\
\hline NP & 109 & 295 & 83 & 117 & 89 & $165+$ & 73 & 97 \\
\hline $\mathrm{RP}$ & 104 & 132 & 123 & 120 & $124 *$ & 113 & 86 & 81 \\
\hline \multirow[t]{2}{*}{ SP } & 237 & 139 & $163 *$ & 97 & $160 *$ & 101 & $138 *$ & 93 \\
\hline & \multicolumn{8}{|c|}{ Occluded P } \\
\hline $\mathrm{NP}$ & 611 & 621 & 747 & 603 & 508 & 568 & 766 & 683 \\
\hline $\mathrm{RP}$ & 945 & 588 & 613 & 547 & 633 & 595 & 709 & 1189 \\
\hline \multirow[t]{2}{*}{ SP } & 659 & 615 & 599 & 598 & 611 & $702 *$ & 665 & 717 \\
\hline & \multicolumn{8}{|c|}{ Organic P } \\
\hline $\mathrm{NP}$ & 125 & 135 & 114 & 112 & 118 & 121 & 84 & 108 \\
\hline $\mathrm{RP}$ & 121 & 121 & 135 & 114 & 119 & 112 & 111 & 96 \\
\hline SP & 158 & 128 & 127 & 122 & 142 & 110 & 88 & 104 \\
\hline
\end{tabular}

${ }^{1} \mathrm{RP}$ - Natural Rock phosphate applied to soybean. ${ }^{2} \mathrm{SP}$ - Soluble phosphorus fertilizer applied to soybean. ${ }^{3} \mathrm{NP}$ - no phosphorus applied to triticale. ${ }^{4} \mathrm{RP}$ - Natural Rock Phosphate applied to triticale. ${ }^{5} \mathrm{SP}$ - Soluble P fertilizer applied to triticale. + + significant difference (LSD. $p<0.05$ ) as compared with Rock phosphate applied to soybean. *significant difference (LSD. $p<0.05$ ) as compared to No P. ${ }^{* *}$ significant difference (LSD. $p<0.05$ ) as compared to Rock Phosphate applied to triticale.

phosphate fertilizer and in those that received natural phosphate (Table 4). After harvesting values (Table 4) when compared with those determined before soybean planting, suggests that application of soluble phosphate prevented the drop in Fe-bound P contents. In contrast, plots that had received RP over RP presented a sharp decrease in Fe-bound $\mathrm{P}$ contents in all studied soil depths.

The use of SP generally resulted in higher Cabound $\mathrm{P}$ contents. However, the differences were not always significant down to the depth of $40 \mathrm{~cm}$. Considering that the phosphates applied have $\mathrm{Ca}$ in their composition, it seems that at least some of the fertilizer did not react with the soil, remaining in its original form. In the same way that in the previous sampling, only the $10-20 \mathrm{~cm}$ layer presented differences for occluded P (Table 4). Contrary to the result obtained before soybean planting, SP led to larger absolute values of occluded phosphorus as compared with those of the other treatments.

Similarly to what was observed in the previous sampling, there were no differences in organic $\mathrm{P}$ due to phosphate sources and ways of application (Table 4). However, in general, the values found at soybean harvest were higher than before planting (Table 3). Selles et al. (1997) reported that organic P built up after five years of zero tillage in the first $4 \mathrm{~cm}$ of the soil and Tokura et al. (2002) also observed an increase in organic P from 5 to $20 \mathrm{~cm}$ deep in no-till as a function of farming time.

Predominant $\mathrm{P}$ fractions in soil were organic and $\mathrm{Fe}$ bound $\mathrm{P}$, in agreement with previous work by 
Almeida et al. (2003) in South Brazilian soils. After soybean harvest, the Fe-bound $\mathrm{P}$ contents were always smaller than before planting (Table 2). In this soil and cropping conditions, $\mathrm{P}$ availability to soybeans was likely related to Fe-bound P, since this was the fraction that decreased in soil after crop.

The sampling carried out after soybean harvest resulted in much lower Fe-bound $\mathrm{P}$ values down to $40 \mathrm{~cm}$ when only NP was used (Table 4). Nevertheless, the use of SP prevented a sharper decrease in Febound $\mathrm{P}$ contents. Thus, apparently, due to its low solubility in soil, NP does not replace the solution P in the time and speed necessary for normal plant growth. However, it is unclear why the Fe-bound P contents in plots that did not receive $\mathrm{P}$ and in plots that received natural phosphate on the surface did not decrease in the same way. Contrary to what had been reported for soils in south Brazil (Selles et al., 1997), it was not observed the build-up of labile fractions of $\mathrm{P}$ in the top soil layer, down to $5 \mathrm{~cm}$.

\section{CONCLUSIONS}

Phosphorus fertilizer application on the soil surface in no-till systems may ameliorate the soil in depth. Regardless of P source, the occluded P in the top soil layers are reduced when compared with a noncropped area. Soybean crop decreases Fe-bound P and increases organic $\mathrm{P}$ in the soil profile.

\section{REFERENCES}

ALMEIDA, J.A.; TORRENT, J.; BARRÓN, V. Cor de solo, formas do fósforo e adsorção de fosfatos em Latossolos desenvolvidos de basalto do extremo-sul do Brasil. Revista Brasileira de Ciência do Solo, v.27, p.985-1002, 2003.

BARBOSA FILHO, M.P.; KINJO, T.; MURAOKA, T. Relações fósforo extraível, frações inorgânicas de fósforo e crescimento do arroz em função de fontes de fósforo, calagem e tempo de incubação. Revista Brasileira de Ciência do Solo, v.11, p.147-155, 1987.

BARTZ, H.R. Dinâmica dos nutrientes e adubação em sistemas de produção sob plantio direto. In: PALLOTTI, A. (Ed.) Plantio direto em solos arenosos: alternativas de manejo para a sustentabilidade agropecuária. Santa Maria: Universidade Federal de Santa Maria, 1998. 103p. (VI Curso de Atualização em Recomendação de Adubação e Calagem).

BAYER, C.; MIELNICZUK, J. Dinâmica e função da matéria orgânica. In: SANTOS, G.A.; CAMARGO, F.A.O. (Ed.) Fundamentos da matéria orgânica do solo: ecossistemas tropicais e sub tropicais. Porto Alegre: Gênesis, 1999. 508p.
CATANI, R.A.; BATAGLIA, O.C. Formas de ocorrência do fósforo no solo Latossolo Roxo. Anais da ESALQ, v.25, p.99-119, 1968.

CHANG, S.C.; JACKSON, M.L. Soil phosphorus fractions in some representative soils. Journal of Soil Science, v.9, p.109119, 1958.

ELTZ, F.L.F.; PEIXOTO, R.T.G.; JASTER, F. Efeitos de sistemas de preparo do solo nas propriedades físicas e químicas de um Latossolo Bruno álico. Revista Brasileira de Ciência do Solo, v.13, p.259-267, 1989.

Empresa Brasileira de Pesquisa Agropecuária - EMBRAPA. S.N.L.C.S: manual de métodos de análise de solo. Rio de Janeiro: Embrapa, 1997. 212p.

JONES, D.L. Organic acids in the rhizosphere: a critical review. Plant and Soil, v.205, p.25-44, 1998.

MACHADO, M.I.C.S.; BRAUNER, J.L., VIANNA, A.C.T. Formas de fósforo na camada arável de solos do Rio Grande do Sul. Revista Brasileira de Ciência do Solo, v.17, p.332-336, 1993.

RAIJ, B. van. Fertilidade do solo e adubação. Piracicaba: Ceres/ POTAFOS, 1991. 343p.

RAIJ, B. van.; ANDRADE, J.C.; CANTARELLA, H.; QUAGGIO, J.A. Análise química do solo para fins de fertilidade. Campinas: Instituto Agronômico, 2001. 285p.

RHEINHEIMER, D.S.; ANGHINONI, I. Distribuição do fósforo inorgânico em sistemas de manejo de solo. Pesquisa Agropecuária Brasileira, v.36, p.150-160, 2001.

ROSOLEM, C.A.; MIYAZAWA, M.; FRANCHINI, J.C.; PAVAN, M.A., COSTA, A. Soil acidity, $\mathrm{pH}$ and aluminium management in tropical soils: the Brazilian experience. In: WORLD SOYBEAN RESEARCH CONFERENCE, 7., Foz do Iguaçu, 2004. Proceedings. Foz do Iguaçu: EMBRAPA, 2004. p.310318.

SCHLINDWEIN, J.A.; ANGHINONI, I. Variabilidade vertical de fósforo e potássio disponíveis e profundidade de amostragem do solo no sistema plantio direto. Ciência Rural, v.30, p.611617, 2000.

SELLES, F.; KOCHHANN, R.A.; DENARDIN, J.E.; ZENTNER, R.P.; FAGANELLO, A. Distribution of phosphorus fractions in a Brazilian Oxisol under different tillage systems. Soil and Tillage Research, v.44, p.23-34, 1997.

SIDIRAS, N.; PAVAN, M.A. Influência do sistema de manejo do solo no seu nível de fertilidade. Revista Brasileira de Ciência do Solo, v.9, p.249-54, 1985.

SMITH, A. N. The uptake of phosphorus by wheat and clover from four inorganic soil phosphate fractions after the addition of contrasting types of phosphatic fertilizer. Plant and Soil, v.29, p.144-55, 1968.

TOKURA, A.M.; FURTINI NETO, A.E.; CURI, N.; FAQUIM, V.; KURIHARA, C.H.; ALOISI, A.A. Formas de fósforo em solo sob plantio direto em razão da profundidade e tempo de cultivo. Pesquisa Agropecuária Brasileira, v.37, p.1467-1476, 2002.

VERNETTI JÚNIOR, F.; GOMES, A.S. Plantio direto: uma opção de manejo para a produção agrícola sustentável. Pelotas: Embrapa Clima Temperado, 1999. 69p. (Documentos, 58).

Received February 06, 2007

Accepted November 11, 2007 